\title{
Training with videogames for improving sustained attention in children with a high risk of learning disorders
}

\author{
Lourdes Guitart Pérez-Puelles \\ Dayamith Menéndez Mendoza \\ Universidad de Ciencias Pedagógicas Enrique José Varona. Cuba. \\ antonrecio39@gmail.com \\ dayamithmm@ucpejv.edu.cu \\ Jesús Eladio Sánchez García \\ Instituto de Cibernética, Matemática y Física. Cuba. \\ gpoest@icimaf.cu \\ Rosario Torres Díaz \\ Centro de Neurociencias de Cuba. Cuba. \\ rosario@cneuro.edu.cu
}

Received: 9/1/2021

Accepted: 3/5/2021

Published: 31/1/2022

\begin{abstract}
Most studies examine the effects of videogames on the cognitive abilities of young and adult players in experimental situations or for rehabilitation purposes. The aim of the present study is to evaluate the use of computerized commercial games for training sustained attention in primary school children at a high risk of learning disorders. A continuous performance task was used to assess sustained attention in a pre- and post-intervention classical paradigm. The training was organized in groups according to the children's age and grade and planned in 30-minute sessions twice weekly for 12 weeks. The Student's $t$-test was statistically significant for the mean reaction times, showing lower response times after training. It was demonstrated that more than twelve videogame sessions are needed to decrease the reaction time (mean RT) as significant relationship with sustained attention. Statistically significant results by age and grade were achieved before training, while at the end of the intervention only age had the same significance in the three age groups in relation to the mean RT. The results of the study suggest the need to continue exploring videogames in children at high risk of learning disorders.
\end{abstract}

Keywords: learning disorders; psychopedagogy; sustained attention; training; videogame

Resum. Formació amb videojocs per a la millora de l'atenció sostinguda en nens amb un alt risc de trastorns de l'aprenentatge

La majoria dels estudis examinen els efectes dels videojocs sobre les capacitats cognitives dels joves jugadors i adults en situacions experimentals o amb finalitats de rehabilitació. L'objectiu de l'estudi és avaluar l'ús de jocs comercials informatitzats per a la formació d'atenció sostinguda en nens amb un alt risc de trastorns de l'aprenentatge en una mostra de 32 escolars de primària. Es va utilitzar una tasca d'execució contínua per avaluar l'aten- 
ció sostinguda en un paradigma clàssic pre- i postintervenció. La formació es va organitzar en grups d'edat i grau i es va planificar en sessions bisetmanals de 30 minuts durant 12 setmanes. La prova $t$ de Student va ser estadísticament significativa per a la mitjana dels temps de reacció després de la formació. Es va demostrar que es necessiten més de 12 sessions de videojocs per reduir el temps mitjà de reacció com a indicador de l'atenció sostinguda. Es van obtenir resultats estadísticament significatius per edat i nota abans de la formació, mentre que al final de la intervenció només l'edat va guanyar la mateixa importància. Els resultats de l'estudi suggereixen la necessitat de continuar explorant l'ús de videojocs en nens amb un alt risc de trastorns de l'aprenentatge.

Paraules clau: atenció sostinguda; formació; psicopedagogia; trastorns de l'aprenentatge; videojocs

Resumen. Entrenamiento con videojuegos para mejorar la atención sostenida en niños con alto riesgo de trastornos del aprendizaje

La mayoría de los estudios examinan los efectos de los videojuegos sobre las habilidades cognitivas de jugadores jóvenes y adultos en situaciones experimentales o con fines de rehabilitación. El objetivo del estudio es evaluar el empleo de juegos comerciales informatizados para el entrenamiento de la atención sostenida en niños con alto riesgo de trastornos del aprendizaje en una muestra de 32 escolares de primaria. Se utilizó una tarea de ejecución continua para evaluar la atención sostenida en un paradigma clásico pre- y postintervención. El entrenamiento se organizó en grupos según la edad y el grado y se planificó en sesiones bisemanales de 30 minutos durante 12 semanas. La prueba $t$ de Student fue estadísticamente significativa para la media de los tiempos de reacción después del entrenamiento. Se demostró que se necesitan más de 12 sesiones de videojuegos para reducir el tiempo promedio de reacción como indicador de la atención sostenida. Se obtuvieron resultados estadísticamente significativos para la edad y el grado antes del entrenamiento, mientras que, al concluir la intervención, solo la edad obtuvo igual significación. Los resultados del estudio sugieren la necesidad de continuar explorando el uso de videojuegos en niños con alto riesgo de trastornos del aprendizaje.

Palabras clave: atención sostenida; entrenamiento; psicopedagogía; trastornos del aprendizaje; videojuegos

\author{
Summary \\ 1. Introduction 4. Discussion \\ 2. Method Bibliographical references
}

3. Results

\title{
1. Introduction
}

Improvements in a wide spectrum of psychological processes following the use of videogames (VGs) have been reported in previous research. The following are among the study topics associated to the use of VGs for developing cognitive abilities: visual selective attention (Green $\&$ Bavelier, 2003); visual attention in reading (Antzaka et al., 2017), spatial cognition (Spence \& Feng, 
2010); flexibility and cognitive control (Colzato et al., 2013); numerical training skills (Sella et al., 2016; Holguín Álvarez et al., 2020); thinking skills (Rivera Arteaga \& Torres Cosio, 2018); learning abilities (Zhao \& Linaza, 2015) as well as a tool for primary education in general (Solano Nogales \& Santacruz Valencia, 2016; López Raventós, 2016). It has been found that action VG have stronger effects on tasks requiring attentional control (Cardoso-Leite \& Bavelier, 2014). Dale et al. (2020) proved that role-playing VGs also showed cognitive performance similar to action VGs. Hedges et al. (2013) asserted that the time devoted to games and other temporal patterns like the language cadence of different kinds of games have a close relationship with learning and repetition.

Educators consider that mathematics and the natural and social sciences can be learned better with the use of VGs and that they also contribute to the development of cognitive abilities (Vázquez-Alonso \& Manassero-Mas, 2017). Successful intervention strategies with VGs have been reported to improve cognitive abilities in children with attention deficit and hyperactivity disorders (González Calleros et al., 2019; Rivera-Flores \& Vera-Álvarez, 2019; Garnica Estrada et al., 2016; Sevilla Ruano, 2019), dyslexia (Jiménez-Porta \& Diez Martínez Day, 2018) and special education needs (Sánchez-Rivas et al., 2017).

Nevertheless, other studies have pointed out some disadvantages. Metaanalyses on the impact of VGs on cognitive abilities have not found consistent effects indicating significant improvements in the acquisition of these abilities (Powers et al., 2013). No transfer effects of acquired skills in a specific field to other fields were found for VG players either, although some authors have highlighted that playing certain kinds of VGs may be related with specific cognitive abilities such as attention, spatial ability and the improvement in reaction times (RT) among players (Sala et al., 2018).

In a wide review of studies concerning VGs, Dale and Green (2017) suggested using indicators related with the evolution of these technologies to analyze their effects on cognitive abilities (i.e., history of video gamers, specialization in type of game and demographic characteristics), which have not been considered in the aforementioned meta-analyses.

In the authors' opinion, the criticism about the VG contents are not warranted in the case of training studies in educational contexts under controlled situations where the contents and the kind of games are selected and the training times are established. Most studies have examined the effects of VG on the cognitive abilities of young and adult players in experimental situations, in the improvement of behaviors associated with ADHD or aimed at rehabilitating senior citizens or for the treatment of dyslexic children (Dale \& Green, 2017).

Moreover, VGs have also been criticized for their contents and excessive use due to their negative effect on behavior such as social isolation, aggressiveness, encouragement of sexism, and addiction (De Sanctis et al., 2017; GómezGarcía et al., 2017). Likewise, the lack of research on VG in learning with pre- and post-tests, where control and experimental groups are used has also 
been criticized, as well as the scarcity of longitudinal studies relating academic performance and VG use (Parada Castro et al., 2018).

It would be very beneficial to go deeper into the relationship between VGs and attention with a view to introducing effective strategies in the diagnosis and treatment of children with learning disorders (LD). Studies carried out in Cuba report an average of 12 to 16 out of 100 pupils suffering from LD (Navarro et al., 2009). Inattention has a high frequency in LD as well as in the majority of neuropsychological disorders. Very frequently, LD present comorbidity with behavioral disorders where inattention, impulsiveness, and hyperactivity are also associated with difficulties for directing and maintaining attention (Pizarro-Pino et al., 2019).

Posner and Petersen (1990) were among the first to conceive of attention as a system of anatomical networks performing alert, orientation, and focused or executive attention functions in an interconnected way. They explained the role of the executive attention network in the cognitive and emotional selfcontrol in provoking normal or pathological behavior (Posner \& Petersen, 1990; Petersen \& Posner, 2012). Nigg (2016) presented evidence of the role played by attention due to its regulating function and its relationship with cognitive flexibility in factors related to school learning.

During the school years, a maturing of the neural structures takes place with consequent manifestations in the cognitive function. According to Álvarez et al. (2013) a particular change in the processing speed measured by RT occurs between the age of seven and nine years. The evolutionary period of attentional changes is critical for psychopedagogical interventions in children reported by their teachers to have possible learning disabilities. These difficulties become evident during the early school years and if they are not treated on time, they can build up and adversely affect adaptation to the school environment.

This research aims to analyze the effects of a training program using commercial VGs on variables of sustained attention in children aged six to twelve years old at high risk of learning disorders. A sectional study was designed to evaluate the training effects by means of a pre- and post-intervention test. The following hypothesis was proposed: Training with action video games for 12 weeks reduces the mean reaction times in sustained attention evaluated by a continuous performance test in school-age children at high risk of learning disorders.

\section{Method}

\subsection{Participants}

The study was carried out in a non-random sample of 32 children from second to sixth grade showing a high risk of learning disorders from four elementary schools located in Havana city urban areas featuring high social vulnerabilities (mean age $=8.97 ; \mathrm{SD}=1.616$ ). Table 1 shows the distribution of the sample by age and gender. Since the children's age was distributed into 7 categories, 
but 2 of them had only one child ( 6 and 12 years old), we decided to form 3 age groups for the analysis (Group 1: 6 and 7 years old, Group 2: 8 and 9 years old, and Group 3: 10, 11 and 12 years old). None of the children had a record of severe neurological, psychiatric, or sensorial disorders. The sample selection complied with a diagnosis performed using the Questionnaire on Risk Signs of Learning Disorders (QRS-L) administered in the first two months of the school year. All of the children had played VGs at home on a regular basis.

Table 1. Sample description by grade, age, gender, and QRS-L

\begin{tabular}{cccc}
\hline Grade & Mean age (SD) & Total (male) & QRS-L (SD) \\
\hline 2 & $6.88(0.354)$ & $8(6)$ & $2.88(0.354)$ \\
3 & $8.00(0.000)$ & $5(2)$ & $3.00(0.000)$ \\
4 & $9.00(0.000)$ & $6(4)$ & $2.67(0.516)$ \\
5 & $10.33(0.500)$ & $9(8)$ & $3.00(0.000)$ \\
6 & $11.25(0.500)$ & $4(3)$ & $2.50(1.000)$ \\
Total & $8.97(1.616)$ & $32(23)$ & $2.84(0.448)$ \\
\hline
\end{tabular}

Source: Own elaboration.

\subsection{Materials}

\subsubsection{Questionnaire of Risk Signs and Learning Problems (QRS-L)}

The QRS-L is an instrument to measure disorders in school children contained in the Optima-Pesquisa that classifies children in three risk levels: high risk, moderate risk, and no risk, based on the sum of the total reported signs of risk (Reigosa-Crespo et al., 2012). The questionnaire contains a list of 20 behaviors that are easily observable in the classroom and related to three academic learning areas: Reading (6 items), Writing (6 items), and Mathematics (8 items). The teacher must answer whether the behavior is present or not in each child.

\subsubsection{Continuous Performance Test}

The Continuous Performance Test (CPT) is frequently used for evaluating sustained attention. The variables for measuring the performance of the tasks are: correct hits $(\mathrm{CH}$ : number of times the subject correctly reacts to the appearance of the target letter;) omission errors (OE: number of times the subject does not react to the appearance of the target letter;) commission errors (CE: number of times the subject reacts to the appearance of a letter different from the target one); the mean reaction time (MRT in ms) and the mean value of the standard deviation (SDRT; dispersion of the RT with respect to the mean value of the RT's of the right answers). 


\subsubsection{VINCI Software}

The pre- and post-intervention in sustained attention was evaluated using VINCI software (VINCI v1.0 (BETA), 2008). It contains a task for evaluating sustained attention in the version of the CPT. During the test, the child is presented a series of stimuli (letters) in a consecutive manner and must react to them by pressing the space bar as soon as possible every time the stimulus previously indicated as the target appears (in this case letter A in yellow). In the present study, four ten-stimuli blocks were used. The exhibition and hiding time of the letter was $500 \mathrm{~ms}$. The CPT variables previously described were used before the training: CHpre, OEpre, CEpre, MRTpre and SDRTpre) and after (CHpos, OEpos, CEpos, MRTpos and SDRTpos).

\subsection{Procedures}

The parents were initially interviewed to obtain their informed consent for the training of their children and they also answered questions about the children's behavior at home.

The training was programmed during the second semester of the 20182019 school year for the whole sample simultaneously. It was carried out using six pairs of commercial action VGs previously evaluated by two psychologists and three educators with 15 or more years of professional experience. The VGs were assessed in relation to the presence of the characteristics defined by Green et al. (2010) for action VGs including: action speed, memorization of elements, speed and accuracy of the response, characteristics of the visual scenes, and the aggressivity of the game on a scale of almost always (2), sometimes (1), and never (0). The score given to the VGs allows their classification according to the difficulty level in the action and aggressiveness categories. 2D action games were used and organized for each session according to the total score given to each VG by the experts. The reserve games had the same score as those selected for the session.

The training was programmed in twice- weekly, 30-minute sessions for 12 weeks. Each pair of VGs was presented for only two weeks. The VGs were presented in increasing order of difficulty. The sessions took place in the computer labs at the schools, in groups of 6 or 7 children during the afternoon session. Two VGs with the same level of difficulty were used in each session and one was held in reserve just in case a child showed signs of boredom, demotivation, or other behaviors requiring a change of activity. Each session was attended by two coaches who were responsible for the application of the $\mathrm{VG}$ and of keeping a record of observations. Before the beginning of each session the instructions for the first VG were given. If a child rejected the task, the second VG was opened and if the child did not react, the reserve VG was used. The sessions lasted 30 minutes. 


\subsection{Statistical Analysis}

SPSS v. 22 statistical software was used for the data analysis. Descriptive statistics were employed for a general characterization of the variables and the standard scores (Percentile $\mathrm{Z}$ and T-scores) to determine the individual profiles of the children before and after the training. A factorial analysis of the main components was done to determine the data structure and weight of the variables relative to sustained attention in the pre- (Epre) and post- (Epos) trainings. In order to compare attention performance in both samples, a Student's $t$-test for related samples with a significance level of $\alpha=0.05$ was used. Given that the total number of children did not participate in the 24 scheduled training sessions, the sample (Epos) was divided into G1 (60\% of the children with 12 or less training sessions) and G2 (40\% of the children with 13 to 21 sessions). The variables of attention were compared in both groups (G1 and G2) using the Student's $t$-test for independent samples. The simple classification ANOVA test (one way) was used to determine the influence of the age groups and sex in the attention variables $(\mathrm{CH}, \mathrm{CE}, \mathrm{RT}$, and SDRT) in both Epre and Epos. Tukey's HSD multiple comparison test was used for the analysis of variables with significant results. The two-way ANOVA with interactions was employed to determine the possible influence of age on the results of G2.

\section{Results}

\subsection{Suitability of the attention variables}

The principal component analysis for Epre shows a moderate relationship among the variables grouped in four factors; the first two components explain $66.95 \%$ of the total variance. The first component shows a relationship between the mean $\mathrm{CH}$ pre (MCHpre) and MRTpre with different signs. In the second component, the mean CEpre (MCEpre) and SDRTpre had the highest weights, indicating a large variability among the children who make mistakes of commission. In Epos, the first two components explain more than $75 \%$ of the total variance, the first of them having $48.94 \%$. In this case we found a higher weight for the mean CEpos (MCEpos) and SDRTpos in the first component, while the mean $\mathrm{CH}$ pos (MCHpos) and MRTpos were the most important variables in the second component coinciding with the first component for the Epre sample, but with the same sign, as shown in Table 2. 
Table 2. Factor matrix for the principal component analysis in Epre and Epos

\begin{tabular}{lccccc}
\hline Epre & Factor 1 & Factor 2 & Epos & Factor 1 & Factor 2 \\
\hline MCHpre & -0.718 & -0.357 & MCHpos & -0.277 & 0.761 \\
MCEpre & 0.451 & 0.690 & MCEpos & 0.937 & 0.261 \\
MRTPre & 0.813 & -0.192 & MRTpos & -0.205 & 0.557 \\
SDRTpre & 0.127 & 0.801 & SDRTpos & 0.960 & 0.095 \\
\hline
\end{tabular}

Source: Own elaboration.

\subsection{Improvement of $R T$ with $V G$ training}

Figure 1 shows the comparison of Epre and Epos with the $t$-test. As can be seen, the $t$-test was statistically significant in the performances of MRT $(t=4.594, p<0.05)$ with smaller response times after the intervention and also in SDRT $(t=0.537, p=0.003)$. The test was not significant for $\mathrm{CH}$ $(t=0.103, p=0.732)$ and $\mathrm{CE}(t=1.022, p=0.290)$.

Figure 1. Comparison of MRT in Epre and Epos

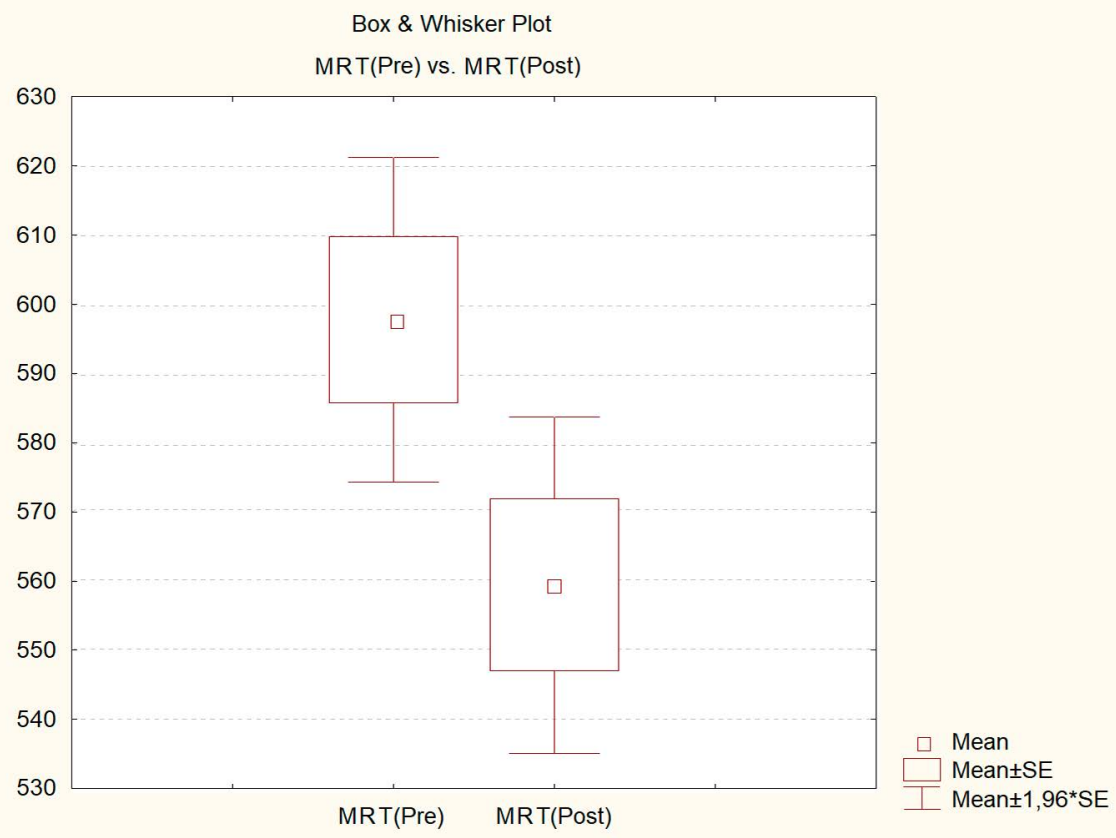

Source: Own elaboration. 


\subsection{VG training is enough with 12 sessions}

The $t$-test comparison of groups G1 (up to 12 sessions) and G2 (more than 12 sessions) was statistically significant only for SDRTpos $(t=2.192, p=0.036)$. In $\mathrm{G} 1$, the variability is bigger (SDRTpos in $\mathrm{G} 1=121.89$ and in $\mathrm{G} 2=83.20$ ). No significant differences were found for $\mathrm{CH}(t=0.742, p=0.468)$, CE $(t=-1.827, p=0.79)$ and RT $(t=1.22, p=0.232)$.

\subsection{Effects of age, grade, and sex on the pre-and post-training samples}

The analysis of variance (ANOVA) for Epre showed an effect of age on MCEpre $(F=5.328, p=0.11)$ and on SDRTpre $(F=6.122, p=0.006)$, while in Epos only RT was significant (MRTpos: $F=6.203, p=0.006$ ).

With respect to grade, as it was expected, significant differences are found for the ANOVA of MCEpre $(F=2.904, p=0.04)$ and also for SDRTpre $(F=3.115, p=0.031)$. Nevertheless, effects of the grade for Epos are found in MCHpos $(F=4.404, p=0.007)$ and in MRTpos $(F=3.815, p=0.014)$.

Tukey's HSD showed differences between age groups 1 and 3 , that is, children between 6 and 7 years old and those between 10 and 12 years old in MCEpre $(p=0.009)$ and SDRTpre $(p=0.04)$. In Epos, the three age groups were different for MRTpos (6-7 vs. $10-12, p=0.029$; 8-9 vs. 10-12, $p=0.010$ ).

Table 3. Results of the Tukey test for age group in the variables CE, RT and SDRT for Epre and Epos

\begin{tabular}{|c|c|c|c|c|c|}
\hline (I) age groups & (J) age groups & Var dep & Sig. & Var dep & Sig. \\
\hline \multirow{2}{*}{1} & 2 & \multirow{4}{*}{ MCEpre } & .396 & \multirow{4}{*}{ MCEpos } & .906 \\
\hline & 3 & & .009 & & .666 \\
\hline \multirow{2}{*}{2} & 1 & & .396 & & .906 \\
\hline & 3 & & .132 & & .886 \\
\hline \multirow{2}{*}{1} & 2 & \multirow{4}{*}{ MRTpre } & .987 & \multirow{4}{*}{ MRTpos } & .982 \\
\hline & 3 & & .502 & & .029 \\
\hline \multirow{2}{*}{2} & 1 & & .987 & & .982 \\
\hline & 3 & & .345 & & .010 \\
\hline \multirow{2}{*}{1} & 2 & \multirow{4}{*}{ SDRTpre } & .083 & \multirow{4}{*}{ SDRTpos } & .996 \\
\hline & 3 & & .004 & & .537 \\
\hline \multirow{2}{*}{2} & 1 & & .083 & & .996 \\
\hline & 3 & & .404 & & .534 \\
\hline
\end{tabular}

Source: Own elaboration. 
The Tukey test found no differences for grade or the CE in Epre but it did find significant differences between second and sixth grade for the standard deviation (SDRTpre $p=.034$ ). Tukey's HSD gives differences in Epos for the mean $\mathrm{CH}$ between the third and fourth grades (MCHpos, $p=.016$ ) and between the third and sixth grades (MCHpos, $p=.006$ ). However, in the case of the mean RT. However, in the case of the mean RT difference was only found between the third and the sixth grades (MRTpos, $p=.030$ ).

There were no differences in sex using the one-way ANOVA in the preand post-samples for any attention variable Epre: (MCHpre $F(.204) p=.654$; MCEpre $F(.107) p=.746$; MRTpre $F(.527) p=.474$ and SDRTpre $F(.092)$ $p=.763)$. Epos: (MCHpos $F(1.973) p=.170)$; MCEpos $F(1.369) p=.251$; MRTpos $F(.244) p=.325$ and SDRTpos $F(.831) p=.369)$.

\section{Discussion}

The main finding of this study is the improvement in the mean values of RT in children at high risk of learning disorders by means of VG training. Yuji (1996) found excellent perceptual motor abilities as well as of information processing in children playing VGs and quicker reactions in those who had experiences with these technologies. Dye et al. (2009) provided evidence of quicker RT without a notable loss of precision in players of action VGs using the attention network test (ANT), a measure of efficiency of the three different functions of attention. Similar results were found by Green and Bavelier (2012) where action VGs accelerate RT, especially in visual and hearing tasks. The obtained benefits in RT can also indicate a growth in the attention abilities and contribute to improve the reading ability as Antzaka et al. (2017) found.

Additionally, the decrease in RTs with training shows a higher processing speed or motor response that are indicators of cognitive efficiency and processing ability (Riccio et al., 2001). In contrast, the precision indicators indicated by Epstein et al. (2003) that are given by the number of $\mathrm{CH}$ (general accuracy), OEs (associated with attention issues) and CEs (impulsivity and hyperactivity) could not lead to improvements with the VG. The mean values of these three indicators $(\mathrm{CH}, \mathrm{OE}$, and $\mathrm{CE}$ ) were non-significant before and after the VG training. Additionally, the inverse relationship in the first component between the mean values of $\mathrm{CH}$ and $\mathrm{RT}$ confirms there was no improvement in $\mathrm{CH}$; that is: trained children were quicker, but not more accurate.

The group with up to 12 sessions (G1) showed a greater variability in the mean values of the standard deviation with respect to the group with more than 12 sessions (G2) and this was the only significant variable. The standard deviation of RT is a measure of consistency and the ability to maintain attention over time (Riccio et al., 2001). Therefore, the children in group 1 (G1) were less consistent and found it more difficult to maintain attention. This means that more than 12 training sessions are needed to achieve sustained care improvements. 
The age and grade effects that were found in the sample before the training (Epre) for CE and SDRT are as expected and indicate the large variability in the performance of the children of different grades and ages, especially those belonging to separate age groups ( 6 and 7 years vs. 10 to 12 years). After training, age influences RT (differences were found among the three groups). Grade also affects the right answers, where the differences are visible between the third and fourth and third and sixth grades. For the last pair of grades there are also differences in RT. Rueda et al. (2004) experimented with ANT and found important changes in the alert network between 6 and 10 years old with respect to RT and error rates. This is confirmed by the results obtained in this study because the 6- and 7-year-old children showed slower RT in comparison with the 11- and 12-year-old children, but all the ages groups improved RT with the training, thus confirming the value of VGs for improving attention.

With respect to gender, no significant differences were found for the variables CH, CE, MRT and SDRT before and after the treatment. Dye et al. (2009) found no significant differences in RT in an analysis using the ANT test with a group of players and they suggest that gender is not a measurement of impact on RT results in the age groups studied by them.

The fact that RT was reduced after the training indicates an improvement in attention processes. As stated by Roncancio-Ortiz et al. (2017), action VGs have the peculiarity of proposing an activity that allows obtaining fast responses through actions meeting game requirements and contributes to improve attention.

The obtained benefits in terms of RT also indicate an improvement in visual attention abilities and reading skills (Antzaka et al., 2017). Teachers have also reported the benefits of these interventions which, according to the results, could be due to possible improvements in the ability of quicker learning due to the indirect effects on attention (Vázquez-Alonso \& ManasseroMas, 2017; Holguín Álvarez et al., 2020).

In their research, Parada Castro et al. (2018) referred to the use of VGs for improving cognitive processes where attention was the only process presenting a statistically significant improvement. In this regard, the authors confirmed the theories developed by Trick et al. (2005); Green and Bavelier (2003); Dye et al. (2009) and Spence and Feng (2010), who conceptualize VGs as tools with the capacity to increase players' attention.

Recently, the development of virtual reality technologies has shown improvements in different domains (sensorimotor rehabilitation, in patients suffering from amnesia, effective instructions in the learning of sciences and second languages), as well as in learning as a whole, due to their characteristics of immersion and interaction and to the learners' cognitive abilities (Li et al., 2020).

On the other hand, the strong relationship between the performance in the CPT and the direct observation of the behavior suggests that CPTs have moderate to high ecological validity (Riccio et al., 2001) although the validity coefficients are lower than expected as a direct consequence of the multi- 
faceted nature of attention and executive control. These results can be related to the reports of the teachers of the children under study during the application of the Questionnaire of Risk Signs and Learning Problems and of the observers in the observation records of the VG sessions who signaled the inattentive, restless, and in some cases impulsive behavior of some of these children.

The fact that this is an observational study that does not intend to make generalizations is among the main limitations of this study. The variability in $\mathrm{RT}$ found in the groups of the children receiving 12 or more sessions provides evidence of the importance of adjusting the VG characteristics to the children's needs and revaluating the VG sessions and the time assigned to each session (Hedges et al., 2013). With regard to the CPT, the fact that it has presented four blocks of 10 (objective) stimuli instead of 10 or 12 blocks, with a letters exposure time of $500 \mathrm{~ms}$, may be a conditioning factor of the low accuracy found in the sample, which consisted of children with LD.

In conclusion, the contribution of this study supports the need to continue studying VG in schools as agents of change and new pedagogical approaches that allow greater efficiency of teaching-educational processes as well as the prevention and intervention of possible learning difficulties and other neurodevelopment disorders through the introduction of technologies.

\section{Bibliographical references}

Álvarez, M. A., Trápaga, O. M., \& Morales, V. C. (2013). Principios de Neurociencias para psicólogos (2nd edition). Buenos Aires: Paidós.

Antzaka, A., lallier, M., Meyer, S., Diard, J., Carreiras, M., \& Valdois, S. (2017). Enhancing reading performance through action video games: The role of visual attention span. Scientific Reports, 7, 14563. <https://doi.org/10.1038/s41598-017-15119-9>

Cardoso-Leite, P., \& Bavelier, D. (2014). Video game play, attention, and learning: How to shape the development of attention and influence learning? Current Opinion Neurology, 27(2), 185-191. $<$ https://doi.org/10.1097/WCO.0000000000000077>

Colzato, L. S., Van den Wildenberg, W. P., Zmigrod, S., \& Hommel, B. (2013). Action video gaming and cognitive control: Playing first person shooter games is associated with improvement in working memory but not action inhibition. Psychological Research, 77(2), 234-239. <https://doi.org/10.1007/s00426-012-0415-2>

Dale, G., \& Green, S. C. (2017). The changing face of video games and video gamers: Future directions in the scientific study of video game play and cognitive performance. Journal of Cognitive Enhancement, 1, 280-294. <https://doi.org/10.1007/s41465-017-0015-6>

Dale, G., Kattner, F., Bavelier, D., \& Green, C. S. (2020). Cognitive abilities of action video game and role-playing video game players: Data from a massive open online course. Psychology of Popular Media, 9(3), 347-358. $<$ https://doi.org/10.1037/ppm0000237>

De Sanctis, F., Distéfano, M., \& Mongelo, M. (2017). Efectos positivos y negativos en la psicología de los videojuegos [Positive and negative effects in the 
psychology of videogames]. Acta Psiquiátrica y Psicológica de América Latina, 63(2), 115-131. Retrieved from <https://repositorio.uca.edu.ar/handle/123456789/ $6180>$.

Dye, M. W. G., Green, C. S., \& Bavelier, D. (2009). The development of attention skills in action video game players. Neuropsychologia, 47(8-9), 1780-1789. $<$ https://doi.org/10.1016/j.neuropsychologia.2009.02.002>

Epstein, J. N., Erkanli, A., Conners, K. C., Klaric, J., Costello, J. E., \& ANGOLD, A. (2003). Relations between continuous performance test performance measures and ADHD behaviors. Journal of Abnormal Child Psychology, 31(5), 543-554. <https://doi.org/10.1023/A:1025405216339>

Garnica Estrada, E., Quiroga López, B., Miranda Castro, P., \& Medina León, A. (2016). Diseño de módulos interactivos para tratar el trastorno por déficit de atención con hiperactividad- TDAH [Design of interactive modules to treat attention deficit hyperactivity disorder - ADHD]. Revista Ingeniería, Matemáticas y Ciencias de la Información, 3(6), 49-57. $<$ https://doi.org/10.21017/rimci.2016.v3.n6.a14>

Gómez-García, S., Planells de la Maza, A. J., \& Chicharro-Merayo, M. (2017). ¿Los alumnos quieren aprender con videojuegos? Lo que opinan sus usuarios del potencial educativo de este medio [Do students want to learn using video games? Users' opinions about the educational function of video games]. Educar, 53(1), 49-66. $<$ http://dx.doi.org/10.5565/rev/educar.848>

González Calleros, C. B., Guerrero García, J., \& Navarro Rangel, Y. (2019). Un juego serio para la solución de problemas matemáticos para niños con TDAH [A serious math problem-solving game for children with ADHD]. Campus Virtuales, 8(2), 121-140. Retrieved from <https://www.researchgate.net/publica tion/337196656>

Green, S. C., \& Bavelier, D. (2003). Action video game modifies visual selective attention. Nature, 423, 534-537. $<$ https://doi.org/10.1038/nature01647>

- (2012). Learning, Attentional control, and Action video games. Current Biology, 22(6), 197-206. $<$ https://doi.org/10.1016/j.cub.2012.02.012>

Green, S. C., Li, R., \& Bavelier, D. (2010). Perceptual learning during action video game playing. Topics in Cognitive Science, 2, 202-216. $<$ https://doi.org/10.1111/j.1756-8765.2009.01054.x>

Hedges, J. H., Adolph, K. E., Amso, D., Bavelier, D., Fiez, J. A., Krubitzer, L., McAuley, D., Newcombe, N. S., Fitzpatrick, S. M., \& Ghajar, J. (2013). Play, attention, and learning: How do play and timing shape the development of attention and influence classroom learning? Annals of the New York Academy of Sciences, 1292(1), 1-20. $<$ https://doi.org/10.1111/nyas.12154>

Holguín Álvarez, J., Taxa, F., Flores Castañeda, R., \& Olaya Cotera, S. (2020). Proyectos educativos de gamificación por videojuegos: desarrollo del pensamiento numérico y razonamiento escolar en contextos vulnerables [Educational gamification projects using video games: Development of numerical thinking and school reasoning in vulnerable contexts]. EDMETIC, 9(1), 80-103. $<$ https://doi.org/10.21071/edmetic.v9i1.12222> 
Jiménez-Porta, A. M., \& Diez Martínez Day, M. E. (2018). Análisis del contenido de apps y VJ: implicaciones en procesos cognitivos en la lectura inicial [Content analysis of apps and VG: Implications for cognitive processes in early reading]. Apertura, 10(1), 71-87. $<$ https://doi.org/10.32870/ap.v10n1.1114>

Li, P., Legault, J., Klippel, A., \& ZhaO, J. (2020). Virtual reality for student learning: Understanding individual differences. Human Behavior and Brain, 1(1), 28-36. <https://doi.org/10.37716/HBAB.2020010105>

López Raventós, C. (2016). El videojuego como herramienta educativa. Posibilidades y problemáticas acerca de los serious games [The video game as an educational tool: Possibilities and problems of serious games]. Apertura, 8(1), 00010. Retrieved June 7, 2020, from <http://www.scielo.org.mx/scielo.php?script=sci_ arttextypid=S1665-61802016000200010\&lng=es\&tlng=es $>$.

Navarro, Q., Gayle, M., Pérez, F., Reigosa, C., \& Torres, D. (2009). El trabajo preventivo en el sistema educativo cubano [Preventive work in the Cuban educational system]. La Habana, Cuba: Ministerio de Educación.

Nigg, J. T. (2017). Annual Research Review: On the relations among self-regulation, self-control, executive functioning, effortful control, cognitive control, impulsivity, risk-taking, and inhibition for developmental psychopathology. Journal of Child Psychology and Psychiatry, 58(4), 361-383. <https://doi.org/10.1111/jcpp.12675>

Parada Castro, A., Raposo-Rivas, M., \& Martínez-Figueira, M. E. (2018). ¿Mejorar la atención con VJ? Un estudio de caso [Improving attention with VG? A case study]. REOP, 29(3), 94-109. <https://doi.org/10.5944/reop.vol.29.num.3.2018.23323>

Pizarro-Pino, D., Fuentes Vilugrón, G. A., \& Lagos-Hernández, R. (2019). Programa de desarrollo cognitivo y motor para atención selectiva y sostenida de niños y niñas con TDAH [Cognitive and motor development program for selective and sustained attention in children with ADHD]. Revista Educación, 43(2). <https://doi.org/10.15517/revedu.v43i2.30518>

Petersen, S. E., \& Posner, M. I. (2012). The attention system of the human brain: 20 years after. Annual Review of Neuroscience, 35, 73-89. <https://doi.org/10.1146/annurev-neuro-062111-150525>

Posner, M. I., \& Petersen, S. E. (1990). The attention system of the human brain. Annual Review of Neuroscience, 13, 25-42. <https://doi.org/10.1146/annurev.ne.13.030190.000325>

Powers, K. L., Brooks, P. J., Aldrich, N. J., Palladino, M. A., \& Alfieri, L. (2013). Effects of video-game play on information processing: A meta-analytic investigation. Psychonomic Bulletin \& Review, 20, 1055-1079. <https://doi.org/10.3758/s13423-013-0418-z>

Reigosa-Crespo, V., Valdés-Sosa, M., Butterworth, B., Estévez, N., Rodríguez, M., Santos, E., Torres P., Suárez, R., \& Lage, A. (2012). Basic numerical capacities and prevalence of developmental dyscalculia: The Havana Survey. Developmental Psychology, 48(1), 123-135. $<$ https://doi.org/10.1037/a0025356>

Riccio, C. A., Reynolds, C. R., \& Lowe, P, A. (2001). Clinical applications of continuous performance tests. measuring attention and impulsive responding in children and adults. New York: John Wiley \& Sons. 
Rivera Arteaga, E., \& Torres Cosio, V. (2018). Videojuegos y habilidades del pensamiento [Video games and thinking skills]. RIDE Revista Iberoamericana para la Investigación y el Desarrollo Educativo Iberoam. Investig. Desarro. Educ, 8(16). <https://doi.org/10.23913/ride.v8i16.341>

Rivera-Flores, G. W., \& Vera-Álvarez, A. E. (2019). Intervención computarizada para mejorar la atención sostenida en un niño con TDAH [Computerized intervention to improve sustained attention in a child with ADHD]. Revista de Psicología Clínica con Niños y Adolescentes, 6(1), 6-22. <https://doi.org/10.21134/rpcna.2019.06.1.2>

Roncancio-Ortiz, A., Ortiz-Carrera, M. F., Llano-Ruiz, H., Malpica-López, M. J., \& Bocanegra-García, J. J. (2017). El uso de los videojuegos como herramienta didáctica para mejorar la enseñanza-aprendizaje: una revisión del estado del tema [The use of video games as a didactic tool to improve teaching-learning: A review of the state of the art]. Revista Ingenieria Investigación y Desarrollo, 17(2), 36-46. <https://doi.org/10.19053/1900771X.v17.n2.2017.7184>

Rueda, M. R., Fan, J., McCandliss, B. D., Halparin, J. D., Gruber, D. B., LerCARI, L. P., \& Posner, M. I. (2004). Development of attentional networks in childhood. Neuropsychologia, 42(8), 1029-1040. $<$ https://doi.org/10.1016/j.neuropsychologia.2003.12.012>

Sala, G., Tatlidil, K., \& Gobet, F. (2018). Video game training does not enhance cognitive ability: A comprehensive meta-analytic investigation. Psycological Bulletin, 144(2), 111-139. <https://doi.org/10.1037/bul0000139>

Sánchez-Rivas, E., Ruiz-Palmero, J., \& Sánchez-Rodríguez, J. (2017). Videojuegos frente a fichas impresas en la intervención didáctica con alumnado con necesidades educativas especiales [Video games versus printed cards in a teaching implementation with special educational needs students]. Educar, 53(1), 29-48. $<$ https://doi.org/10.5565/rev/educar.844>

Sella, F., Tressoldi, P., Lucangeli, D., \& Zorzi, M. (2016). Training numerical skills with the adaptive videogame "The Number Race": A randomized controlled trial on preschoolers. Trends in Neuroscience and Education, 5(1), 20-29. <https://doi.org/10.1016/j.tine.2016.02.002>

Sevilla Ruano, K. C. (2019). Juegos interactivos para desarrollar la atención en niños y niñas con trastorno de déficit de atención [Master's thesis, University of Israel]. Retrieved from <http://repositorio.uisrael.edu.ec/handle/47000/1872>.

Spence, I., \& Feng, J. (2010). Video games and spatial cognition. Review of General Psychology, 14(2), 1-13. $<$ https://doi.org/10.1037/a0019491>

Solano Nogales, L., \& Santacruz Valencia, L. P. (2016). Videojuegos como herramienta en Educación Primaria: Caso de estudio con eAdventure [Videogames as a tool in primary education: Case study with eAdventure]. Revista Iberoamericana de Educación en Tecnología y Tecnología en Educación, 18, 101-112. Retrieved from $<$ http://sedici.unlp.edu.ar/handle/10915/58515>.

Trick, L. M., Jaspers-Fayer, F., \& Sethi, N. (2005). Multiple-object tracking in children. "The Catch the Spies" task. Cognitive Development, 20(3), 373-387. <https://doi.org/10.1016/j.cogdev.2005.05.009>

Vázquez Alonso, A., \& Manassero-Mas, M. A. (2017). Juegos para enseñar la naturaleza, el conocimiento científico y tecnológico [Games for teaching the natu- 
re of scientific and technological knowledge]. Educar, 53(1), 149-170.

$<$ https://doi.org/10.5565/rev/educar.839>

Yujı, H. (1996). Computer games and information-processing skills. Perceptual and Motor Skills, 83(2), 643-647. <https://doi.org/10.2466/pms.1996.83.2.643>

Zhao, Z., \& Linaza, J. L. (2015). Relevance of videogames in the learning and development of young children. Electronic Journal of Research in Educational Psychology, 13(36), 301-318.

$<$ https://doi.org/10.14204/ejrep.36.14108> 